\title{
Changing the World Through Poetry: Confessions, Poems and Banners of Adam Borzič ${ }^{1}$
}

\section{The Return of Poetry into the Public Space}

In his book entitled Tváre ve stínu (Faces in the Shadow), which outlines the lives and works of several Czech writers of the first half of the twentieth century, the poet and historian Zdeněk Kalista reminisces about the effect of the first public reading of Vladimir Majakovsky in the early twentieth-century Czechoslovakia: "The public stomped their feet with excitement over the verses of the Left March" (Kalista 136). Although something like this is hard to imagine in the current Czech poetry scene, ${ }^{2}$ literary scientists, critics and poets themselves concur that Czech poetry is more and more boldly breaking into the public sphere. In a 2008 publication entitled $V$ souradnicích volnosti (Within the Coordinates

1 This study has resulted from the Academic Prize awarded to Pavel Janoušek by the Academy of Sciences of the Czech Republic and from long-term support for conceptual development of a research institution; registration number 68378068 .

This work required usage of Czech Literary Bibliography research infrastructure resources (http://clb.ucl.cas.cz).

2 In comparison, in the Ukraine, for instance, current poets address audiences in soldout theatres. See an article: Pazdiorová, Helena. "Jenom psát nestačí. Podoby současné ukrajinské poezie" (Just Writing is not Enough: the Forms of Current Ukrainian Poetry). $A 27$ (2019): 6. 
of Freedom), which maps out Czech literary production of the 1990s, Jiří Zizler talks about how in the post-Velvet Revolution era, Czech poets, after many years of following the main ideology and adjusting their work accordingly, or moving into the unofficial literary realm, "the era of the explicitly engaged tone in poetry and its striking social pathos was over. The only certainty and a common horizon lay in the freedom of creation" (Zizler 18).

Over the first few years of the new millennium the situation is gradually but significantly changing. Karel Piorecký describes the key feature of literature produced during that period as follows: "The majority consensus of literature being apolitical, which was agreed shortly after the so-called Velvet Revolution and determined the subsequent literary discourse" (48) has disappeared. According to him, the social function of poetry is starting to come back and is realised particularly through a direct contact with the readers. "Attempts to find attractive ways of addressing the readers have thus become one of the characteristic features of the noughties" (47). This quest is motivated by an endeavour to become more visible or even more successfulpoetry as though takes the criterion of success to measure the quality of life in the current market-driven world, including marketing mechanisms which this world is built on.

The return of poetry into the public space is realised particularly through a significant increase in the number and popularity of author readings and other forms of public literary events, where a poem may have a direct effect on a larger number of audiences (including those who normally do not read poetry), and thus influence them effortlessly. It is the effect of a poem that constitutes a significant moment when poetry can open itself up to the wider society. Making poetry more visible and effective, an attempt to have as many people as possible hear it-these are just the first steps on a journey which T.S. Eliot outlines in his essay "The Social Function of Poetry" as follows:

We can say that the role of a poet is to serve his nation only indirectly. His immediate responsibility is to serve his own language: firstly, to preserve it and secondly, to cultivate and perfect it. When he expresses what other people feel, he also transforms feelings, as he makes them more conscious. He makes people more aware of what they feel and so he tells them something about themselves.... As our language is constantly changing, our way of life changes under the pressures of various material changes in our surroundings, and if we did not have several personalities who combine exceptional sensibility with an exceptional mastery of the word, our ability to express emotions would wither 
and our capacity to feel with it-we would be left with just the most primitive feelings. (Eliot 78-79)

In a situation where even poets themselves proclaim that "printed poetry is being pushed aside as a relic due to its definitive, closed nature and intimacy of the reader's experience" (Stehlíková 101), author readings are probably the most effective way poetry can make the most significant impact. Using means borrowed from other forms of art and media, they can awaken in people a sensitivity to poetry, and thus, by extension, to the world. The poet Adam Borzič sees the boom in author readings as a hope not only for poets, but also for the entire society:

The fact that, at present, poetry is possibly more listened to than read shows the direction which to take. This is clearly a sign of an era ... that this interest in live readings corresponds with a societal question about how to enliven, repopulate and humanise public space, corresponds with the ability to live more communally. (Borzič 2015)

\section{Care for the Current World}

Care for the world is intrinsic to poetry. The poet always relates to the world sensitively, as he attempts to comprehend the world in some way and record the outcome or process of that understanding. The end of the 2000 s was a period of searching in poetry, when poetry was finding its place in the real world. In 2008, the Fantasía group, who articulated the relation between poetry and the world in their anthology entitled Fantasía (which outlined their programme), responded to this need. The three members of the group, poets Adam Borzič, Kamil Bouška and Petr Řehák, have made several explicit and clear points pronouncing a conception of poetry which allows for a poet's active participation, "engagement" 3 in the world: "The experience of poetry results in an engaged being, engagement in the world, as a reluctance to stand up for something compromises poetry. A poet engages in the world with the intensity of an entire

3 These poets understand engagement differently, more broadly than merely voicing political and social issues in poetry. They are more concerned with individual responsibility, personal responsibility for the written word. Engaged poetry, in its more narrow sense, such as critique of the current social situation, is relatively frequent in the current Czech poetry, but it does not form any coherent stream or a clearly defined group. Poets representing this type of poetry include Milan Kozelka and Jan Těsnohlídek, Jr. 
being" (Borzič, Bouška and Řehák 1). In the programme of the so-called "new pathos" which is desirable precisely because it excludes itself from the indifference and aims to awaken sensibility to the world and its ills through poetry, these authors expressed their conviction that when somebody reads a poem and understands it, s/he can understand him/herself and others a bit better.

The Russian literary theorist and philosopher, Boris Groys, who wrote a book entitled Gesamtkunstwerk Stalin. Rozpolcená kultura v Sovětském svazu (Gesamtkunstwerk Stalin. The Riven Soviet Culture) where he focuses on the Russian between-war avantgarde, characterises the avant-garde art as follows: "The essential pathos [art of the classical avantgarde] lies in the demand to move from description to transformation (Groys 41). In their anthology, the Fantasía group talk about the "new pathos" which "brings poetry which advocates co-responsibility for the state of the world" (Borzič, Bouška and Řehák 1). Advocating co-responsibility for the state of the world means wanting to change it, if it is not satisfactory. Kamil Bouška explicitly expressed the need and desire to change the world in an interview for the A2 cultural journal:

I believe that poetry will closely resemble the human voice and will become indistinguishable from it. Poetry will blend in with behaviour and this behaviour will come out of a certain intensification and refinement of consciousness. It will not be motivated by individual gain but will be characterised by an acute awareness of belonging in the wider world. It will become clear that the way that one relates to the world and his/her surroundings will have to change. And it is possible that it will be the poets who will prove to be the best architects of the changing society and new collective ways. (Bouška 2019: 20)

This claim is pure avant-garde through its provocative and utopian nature, as its historical and societal context is very different from that of Groys's. The Russian avant-garde of the 1920 aimed to hold back the overly technical world by returning to the original, reduced, pure forms which the new world could be based on Malevich's Černý čtverec, zaumný jazyk V. Chlebnikova (Black Square: The Beyonsense Language of $V$. Chlebnikov). The current avant-garde wants to revitalise the world where everything is measured by money, numbers and success, where "the living are ruled by dead objects" through poetry which awakens sensitivity and the sense of belonging with others. In an epilogue to the yearbook entitled Nejlepší české básně 2014 (The Best Czech Poetry of 2014), ${ }^{4}$

4 The publisher Host started publishing the anthology entitled The Best Czech Poems annually in 2009. It was inspired by the us annual anthology The Best American Poetry. 
the poet Olga Stehlíková talks about a conceptual line in the current Czech poetry, ${ }^{5}$ which she defines as avant-garde. In the light of Groys's understanding of the avant-garde art, it may be argued that the current avant-garde poetry is not satisfied with descriptions of the current world through its own means, as this would mean remaining within its limits, but attempts to change it. "As you do not just evoke the demise, / decay, lean years through lean steps, / as you will not stop the decay, you will not escape from prison, / by just describing its walls”, as written in Adam Borzičs poem entitled „In illo tempore” in his collection Orfické linie (The Orphic Lines). And it is the Fantasía group who require the move from portraying the world to transforming it in its programme.

\section{Heart, Head, Hand and Mouth}

Empathy with the world and personal engagement comes naturally to all the three members of the Fantasía group; however, each of them develops this in their work in a different way. In Kamil Bouška's poems, there is a feeling of being something underneath and its distinctive voice develops gradually through twists and roundabouts. This became most apparent in his third collection entitled Inventura (Stocktaking, 2018), where the voice was most intensive and sounded at its deepest and highest levels. In Petr Řehák's collection Násobit ruce (Multiplying Hands, 2014), we need to reconstruct and to get an understanding out of a relatively complicated composition of verses. The poetry of Adam Borzič declares and manifests his passionate personal fascination with the world through a direct, revealing and captivating form, and his poems exude an acute desire to change the world. Borzičs's gesture is rather extensive than intensive, but easily accessible, even catchy. The following sections will attempt to capture Adam Borzičs poetry through this gesture, which spans between a conviction that the world is at a turning point, and an avant-garde desire to change it through poetry. In Borzičs four collections written so far, this gesture takes delicately intimate, acutely physical and even gigantically all-embracing positions, and is realised through the motives of the heart, head, hand and mouth. The following sections will attempt to capture how this gesture changes from one collection to another and evaluate this development in the light

5 Stehlíková refers to the works of authors contributing to the journal Psí vino which was published since 1997 and its last print version was published in the autumn of 2018. She refers to the works of these authors (e.g. Ondřej Buddeus, Olga Pek) as experimental poetry. Among other features, this type of poetry is enriched by methods used in other art forms (e.g. sound poetry) or inclination towards colletive authorship. 
of the above-mentioned perception of the social function of poetry by T.S. Eliot, and in view of the avant-garde desire to change the reality through art.

\section{Heart}

Borzičs first piece, Rozevírání (Opening Up, 2011) already clearly shows the importance of his perception that the world is at a turning point, which is depicted as initiating and opening up of a new space. Borzič delineates, measures up and touches the poetic space with enchantment but also the space which opened up through experiencing poetry

I touched a crack which emerged from a quiet heart's glory, I felt an intangible opening and everything inside me loosed up, creaked, cracked, whimpered. / I called silence and it came.

It entered sun's space naked.

I drank off its forehead, I drank a drop, I drank its liquid fire, I drank a bee, I drank a mountain, a thunder and cloud.

Then it passed me a nail file and disappeared and I cut the bars my opening up"

(“Opening Up")

This collection already hints, most passionately compared to his following collections, at his love of the world in its two dimensions: physical and spiritual. His poems pulsate with an intensity of the newly discovered or revealed being of a poet, which nevertheless does not belong just to the poet himself but is aimed to serve the world: "My heart is a spark. / An electrical mutiny. / The continents sail through its milk. // My heart is torn up from top to bottom. / My heart is black and white and red. / My heart is life and death and more. // My heart is not mine." The poem entitled "Básníkova pýcha” (The Poet's Pride), which these verses come from, opens not only his collection Opening Up but are an introduction to the author's poetics, as several features, which can be observed here, become the constants in his other poems and collections. It is particularly the dominant and strongly accentuated presence of the lyrical subject which is the centre-point of his poems and where all that appears in a poem: every image, association, thought or every glimpsed reality cross paths, mix and integrate. This immodesty and authority ("the poet's pride") is nevertheless always combined with the sense of responsibility and doubts (the poem starts with a question: "Who am I?"), and this refers to whether it is possible to cope 
with this responsibility, including in a physical sense, as the author also feels a physical co-existence with the world: "My heart is torn up from top to bottom." The heart is not only a metaphor for a relationship to the world but also one of the vital organs which is painfully and intensely impacted by experiencing the world. The world runs through the heart in the same way as blood, and only when the heart is about to burst being completely filled with blood through experiencing the world, can that change happen: "It requires a blow. A clap of the heart. / A sweeping gesture of flying blood... / and then / - then- / you flare up" (poem "Pistolnická modlitba" (A Gunman’s Prayer)). In his poem "Červeň: korida" (Redness: A Bullfight), where the active relation of the poetic $I$ to the world peaks and gets concentrated, and this connection is expressed by the red colour, the colour of blood and life which is likened to bullfights: "There always is a bullfight-Our life."

\section{Head}

Borzičss gesture, which is intuitively drawn out in his first collection, is rationalised, developed and deepened in his second collection Počasí $v$ Evropě (The Weather in Europe, 2013). ${ }^{6}$ His initial "opening up" to poetry and the world becomes a starting point of his poems in the second collection. The preceding collection defined a certain space, but the question now is what to make of that space. The question "Who am I?" from the first poem of Opening Up is replaced by another question "What do you want to take note of?" which the lyrical subject poses itself in the first verse of a poem called "Na výběr" (Having a Choice) in The Weather in Europe. This gesture is getting more complicated as the lyrical subject is impacted by problems which trouble the current world. Borzič is more specific in The Weather in Europe. He lets current world events enter his poems (reflections of the economic crisis; the mass murder on the Norwegian island of Utøya; demonstrations in Barcelona), which gives the collection an almost a journalistic feel. Although he travels through specific places (e.g. Barcelona, Florence, Croatia or former Yugoslavia and Norway) on his journey, this geographic placement should not be understood as an attempt to portray these various parts of Europe from a tourist's perspective. Borzič places himself in a role of a citizen of the world, his gesture is all-embracing and he searches for common denominators. He does not perceive Europe in terms of the centre and periphery. The centre for him is everywhere he sees a suffering individual

6 This collection was nominated for the Magnesia Litera prize for poetry. It is one of the most popular literary prizes in the Czech Republic. 
with whom he empathises, and he understands Europe as a uniform territory with the same "weather" all across.

That week a Norwegian

Killed other Norwegians

From a clear

And other side

Hatred

It rained and there was thunder

That week

Not only

In the Croatian

North. ("Weather in Europe")

This is despite his reflecting the variety across Europe:

Just my Hungarian/melancholy is here, Slavonia

is pulling up its stockings

it is chewing a spicy sausage

and blows the Baroque clouds.

Somebody is a Hungarian, somebody a Serb

somebody even a Czech

the archbishop is a German

the Croatian plain is

hospitable

("Slavonská samota" (The Slavonic Solitude)).

The collection is rationalised through its more refined composition, which is achieved through two overlapping levels of poetic account. The first is the mentioned journalistic and documentary; the other is formed by delicately and bitterly lyrical accounts of the poet's personal recollections of initiating moments from his childhood and when he was growing up. These two levels intersect in a metaphor of the glass head where the individual experiences mix with the experiences of empathy with the world:

My glass internal head / revealed in Barcelona’s Jupiter mountain!

My glass head of a painful bolero!

I open its fourth eye / its sadness devours a crab 


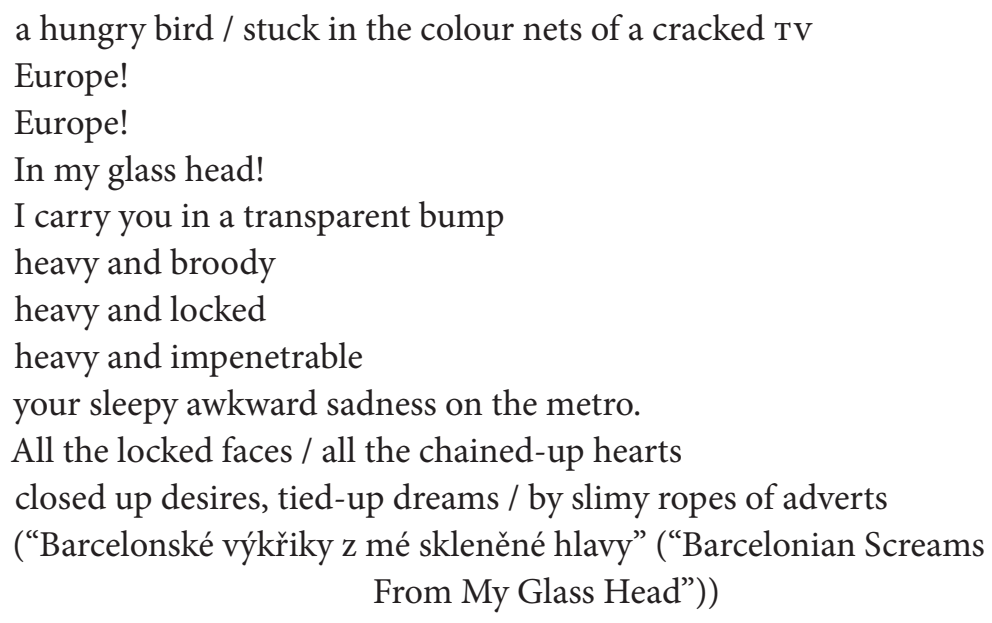

We see two sets of movements: a painful journey through Europe which reminds of: "the live broadcast of twilight / the world how we did not want to know it," and a journey in time, into own past, where these movements are inseparable and undertaken with the same, devastating captivation. The glass head is interpreted in a similar way as the motive of heart in the first poem of the Opening Up collection, figuratively as a space where the reality is played out, experienced and modified, but also as an actual head which may hurt acutely. These two dimensions are inseparable in a similar manner, as it is not possible to separate a head from thoughts and from the body that caries it. The metaphor of the glass head integrates the physicality of experiencing, which is most intense through the use of all the senses and the aspect of rationality which was missing in the previous collection, as the metaphor of heart was more associated with intuition. Compared to the unrestrained nature of the poems in Opening Up, the poems in Weather in Europe and the whole composition of the collection are tighter and more elaborate.

\section{Hand}

Borzičs third collection Orfické linie (The Orphic Lines, 2015) is introduced by the question "Whose history is this?," which is also the title of its first poem. The space was defined in the first collection, then was enriched by the individual time, and the third collection introduced history into it: "What you can see are expanses of time. Spaces of beating time. / What you can hear is clucking of hens in small colonies of the big world. / The sun constantly, CONSTANTLY sets, even sometimes starts scramble up, yet / what you can hear is 
an explosive mixture, the lithospheric plates of history crackle again, / a cut is coming, at this turning point everything is all over the place, / the head can hardly stand, tossed around by gusts / of the twisted time shattered in its own reflection" ("In illo tempore"). His already multi-layered poetic gesture filled with a sharply emotional individuality, which internalises the reality, expands by another dimension-mixing of historical periods with the present or different cultural and artistic traditions and forms and an attempt to embrace it all. The poems again accentuate the tormenting and particularly physically experienced compassion with a human being, this time represented by the motive of a hand: "I will persist / As these words are not detached from my body / After all I write by hand / The same hand / Which I pass day in day out / To the others ..." The metaphor of a hand brings in the subject's action into the poems, an appeal, a call to act, as a hand touches and strokes but can also hit. The poems in The Orphic Lines primarily turn in concentric circles and from different positions identify an awareness of the turning point where the current twisted world is inevitable heading:

\author{
Borders expand. \\ Borders move. \\ Glass shatters. \\ Noise mixes with silence. \\ Hope with murder. \\ What an exciting time.
}

It is as though it got a bit darker and the change was about to happen, as it has not happened yet: “There is something missing in today's drawn-out strokes / whirling spirals of time go down and up / the kairos [right] moment is not coming" ("Vlna" (The Wave)).

The common feature of the poems is a reference to the godly singer, Orpheus. Borzič identifies his role as a poet as somebody who was chosen by gods to charm the mortals and change reality, somebody who sings from darkness into the light. Although Borzičs reinterpretation rather brings light into darkness, in which, according to him, the present is covered: "I can write / Only when I sing into the darkness out of the darkness" (poem "Orfické gesto" (The Orphic Gesture)). The lyrical subject's position is even more unstable than in the two previous collections, as the way he looks around, we sense even deeper empathy, more uncertainty and questions. Compared to the other collections, Borzičss third collection contains poems with more questions. At times, these are sarcastic reflections on the declining present; at times, these are genuine questions 
of a singer asking whether he is on the right track descending from darkness in order to bring light. Sometimes it is an exasperated scream, screams written in blood on banners which he brings to a demonstration.

\section{Mouth}

In Borzičs last collection Západo-východní zrcadla (Westernly Eastern Mirrors, 2018), his lavishly constructed gesture calms down. His gigantic, all-embracing and deeply sensitive $I$, which in its various forms dominated the previous collections, takes the back-stage and virtually disappears in The Mirrors. The poems' expression is simpler. Instead of unrestrained, imaginative verses carried by a fascinating and captivating whirl layering and flowing over images, we read a narrative led virtually in a prosaic rhythm. It is conceptualised as a collection of fictitious utterances of Renaissance artists and philosophers (e.g. Michelangelo, Leonardo da Vinci, Raphael or Botticelli) and Islamic Sufis (Al Ghazali, or Ibn al Arabi) and poems evoking records of humble and loving words mediating wisdom of those who have spoken them. The world imprints itself into the heart, head and hand, which the author dedicated to serve. These motives are reduced to the mouth, which become just a mediator. It does not taste the world, just speaks about it. The didactic tone of the poems derives from the dominant, if constantly doubting, lyrical subject of the previous collections. Passion for the world and awareness of hidden connections between an individual and other people, the present and past do not form an integral part of the poetic expression in The Mirrors, but move to the thematic level. This collection expresses the desire to change the world through poetry in the most extensive way among his collections. Borzič accompanied it with a more than 40-page epilogue, where he clarifies the reasons for writing this collection, reveals the thoughts behind its poems and attempts to explain the unspoken. He is concerned about the impression his poems make on the reader; he wants them to be fully understood and make an impact on an individual and, subsequently, also on the world. At the same time, this collection is one that has the least faith in poetry itself. Poetry becomes just one of the many genres, one of the channels, which is aimed to appeal to the reader to change the world. The poet's gesture of internal engagement, which peaked in Borzičs collections Weather in Europe and The Orphic Lines, is flattened in Westerly Eastern Mirrors.

Borzičs fourth collection symbolises the uncertainty surrounding every public presentation, a view determined and conditioned by time, such as the appearance of the Fantasía group more than ten years ago, and was an allegiance of avant-garde groups to the Russian Revolution. It embodies the sensitivity 
of a demand for the engaged poetry itself. It also symbolises the admirable effort of its author, which can be appreciated when it is contextualised among other work of the author. Adam Borzič is not only a poet but also the editor-in-chief of the fortnightly Tvar (The Form), which is one of the most established journals on the Czech literary scene. In its editorials, which accompany every issue, he tirelessly and enthusiastically defends the revival of the present world, which is, according to him, ruined by the exhausting capitalism, supremacy of market mechanisms which impact not only the everyday life of an individual but also his/her character, cynicism and indifference of one person to another. Although this work is not related to poetry, Borzič undertakes it as a poet and in line with his group's programme, which he helped to formulate. If it is true that "the experience of poetry results in a compassionate being" and "engagement in the world" and a poet "engages [in the world] with an intensity of an entire being," Borzič's work including his poetry may be referred to as cultural work, which really does impact and changes the era, and his poems are one of the means of this revival.

Translated by Pat Mertova

\section{| References}

Borzič, Adam. Rozevírání. (Opening Up). Praha: Dauphin, 2011.

---. Počasí v Evropě. (Weather in Europe). Praha: Malvern, 2013.

---. Orfické linie. (Orphic Lines). Praha: Malvern, 2015.

---. "Poezie a přesah." (Poetry Exceeding Its Role). Deník Referendum (The Referendum Dairy). 2 August 2015, https://tinyurl.com/yxo3u6sd. Accessed 10 December 2019.

---. Západo-východní zrcadla. (Westernly Eastern Mirrors). Praha: Malvern, 2018.

Borzič, Adam, Kamil Bouška and Petr Řehák. Fantasía. Praha: Dauphin, 2008.

Bouška, Kamil. "Čekají nás nové avantgardy. S Kamilem Bouškou o literátštině a čtení poezie." (New Avantgarde’s Await Us: On the Language of Writing and Poetry with Kamil Bouška). A2 4 (2019): 20-21.

Bouška, Kamil. Inventura. (Stocktaking). Praha: Fra, 2018.

Groys, Boris. Gesamtkunstwerk Stalin. Rozpolcená kultura v Sovětském svazu. (Gesamtkunstwerk Stalin. The Riven Soviet Culture). Trans. Martin Ritter, Praha: AvU, 2010.

Eliot, T.S. O básnictví a básnících. (On Poetry and Poets). Trans. Martin Hilský. Praha: Odeon, 1991. 
Kalista, Zdeněk. Tváře ve stínu. (Faces in the Shadow). Praha: Torst, 2016.

Pazdiorová, Helena. “Jenom psát nestačí. Podoby současné ukrajinské poezie." (Just Writing Is not Enough: The Forms of Current Ukrainian Poetry). A2 7 (2019): 9.

Piorecký, Karel. “Česká literární kultura 2001-2010.” (Czech literary culture 2001-2010). V souřadnicích mnohosti: Česká literatura první dekády 21. století $v$ souvislostech a interpretacich. (Within the Coordinates of Plurality: Czech Literature of the First Decade of the 21th Century in its Context and Interpretations). Ed. Alena Fialová. Praha: Academia, 2014. 13-50.

Řehák, Petr. Násobit ruce. (Multiplying Hands). Praha: Malvern, 2014.

Stehlíková, Olga. "Toto nové a to staré" (This New and the Old). Nejlepši české básně 2014 (The Best Czech Poetry of 2014). Ed. Petr Hruška and Olga Stehlíková. Brno: Host, 2014. 96-133.

Zizler, Jiří. “Otevřená dekáda.” (An opened decade.) V souřadnicích volnosti: česká literatura devadesátých let dvacátého století v interpretacích. (Within the Coordinates of Freedom: Czech Literature of the 1990s in Interpretations). Ed. Petr Hruška et al. Praha: Academia, 2018. 11-34.

\section{| Abstrakt}

\section{Markéta Kittllová}

Zmienić świat przez poezję. Wyznania, wiersze i banery Adama Borziča

Artykuł poświęcony został twórczości Adama Borziča, jednego z najbardziej wyrazistych przedstawicieli współczesnej poezji czeskiej. Poza usytuowaniem jego wierszy w kontekście współczesnej poezji czeskiej autorka dąży do zaprezentowania jego działalności artystycznej (i nie tylko) jako sui generis dzieła sztuki, mającego cechy awangardowe. Na podstawie czterech wydanych dotąd tomów poezji Borziča pokazane zostały zmiany widoczne w jego twórczości, oscylującej pomiędzy przekonaniem, że świat znajduje się w punkcie zwrotnym, a awangardowym pragnieniem jego zmiany przez poezję. Gest ten przyjmuje w poezji Borziča postać zarówno kruchych, intymnych, w tym fizycznych, jak i obszernych obrazów. Materializuje się on w motywach serca, głowy, ręki i ust.

Borzič należy do wyrazistych osobowości współczesnej czeskiej literatury. Jego poezję charakteryzuje unikalny gest, jednocześnie jednak reprezentuje on jedną z bardziej zauważalnych tendencji poetyckich ostatnich dziesięciu lat podkreślenie „społeczenej funkcji poezji” (T.S. Eliot) i roli poety jako jednostki, która za pośrednictwem twórczości powinna opiekować się światem, a wręcz 
zmieniać go. Autorka określa Adama Borziča właśnie jako poetę, dzięki któremu tematy te i powiązane z nimi kwestie nabierają aktualności pod koniec pierwszego dziesięciolecia XXI w.

Słowa kluczowe: Adam Borzič; czeska poezja; poezja współczesna; współczesna awangarda

\section{| Abstract}

\section{Markéta Kittllová}

Changing the World Through Poetry: Confessions, Poems and Banners of Adam Borzič

This study focuses on Adam Borzič, one of the most distinctive contemporary Czech poets. The study contextualises his work within current Czech poetry but also examines his other work that is not strictly classified as art as though it were cultural work with avant-garde features. It investigates four volumes of Borzičss work in terms of the changes in the author's creative gesture, which expands from his conviction that the world is at a turning point and the avant-garde longing to change the world by poetry. In the four volumes of Borzič's poetry (written so far), this gesture is embodied through delicately intimate, acutely physical, or even gigantically all-embracing positions, where he employs motives of the heart, head, hand and mouth. The study attempts to evaluate the change in Borzičs work in the light of T.S. Eliot's understanding of the social role of poetry and avant-garde longing to change reality through art.

The Czech poet, Adam Borzič, is one of the most distinctive figures of the current Czech literary scene. His poetry is distinct because of its unique gesture and also represents a strong current in the poetry production of the past decade with its emphasis on the social function of poetry ${ }^{7}$ and the poet's role as somebody who should nurture the world through his/her work or even change it. This study attempts to portray Borzičs work as focused on the mentioned topics and related issues of the end of the first decade of the twenty-first century and renew interest in them, contextualise his work within current Czech poetry but also investigate his other work, which is not strictly artistic but which possesses some avant-garde features.

Keywords: Adam Borzič; Czech poetry; contemporary poetry; contemporary avantgarde

7 I refer to T.S. Eliot's essay “The Social Function of Poetry” written in 1945. 


\section{| About the Author}

Markéta Kittlová has an MA in Czech and Russian Languages and Literatures, Faculty of Arts, Charles University, Czech Republic. She is currently finalising her $\mathrm{PhD}$ on Jiří Weil (Faculty of Arts, Charles University). She works in the Institute of Czech Literature, Czech Academy of Sciences (AV Čr). Her research focus is on the 1920s' and 1930s' Czech literature and current Czech literature. She is a member of the editorial board of Česká literatura.

E-mail: marketa.kittlova@seznam.cz 
